\title{
Deterioro de morteros de cemento producido por la "deposición" seca y húmeda de contaminantes atmosféricos
}

\author{
Dry and wet "deposition" studies of the \\ degradation of cement mortars
}

\author{
S. MARTÍNEZ-RAMÍREZ y G. E. THOMPSON \\ Corrosion and Protection Centre (UMIST), Manchester
}

REINO UNIDO

\section{RESUMEN}

Se han realizado ensayos de laboratorio de simulación de los procesos ambientales de "deposición" seca y húmeda sobre morteros de cemento portland, estudiándose las reacciones que se producen con el contaminante SO. ("deposición seca) y la disolución de 'liuvia ácida' ("deposición" húmeda). Los morteros de cemento se carbonataron para favorecer la carbonatación superficial de los mismos. Se prepararon morteros con dos relaciones a/c con el fin de estudiar la influencia que la variable superficie especifica tenia en el proceso de deterioro de dichos materiales.

En los estudios de deposición seca con So como gras agresivo se ha visto la importancia que el agua y el agua junto a un oxidante tienen en la reacción del contaminante con los componentes del mortero. La superficie expecifica juega un papel importante, ya que al aumentar, aumenta la reaccion con el contaminante. La reacción en presencia de oxidante, $\left(\mathrm{SO}_{2}+\mathrm{O}_{3}\right)$ es inferior en medio con aporte sólo de SO. Los estudios de deposición himedo usando una disolución de 'Iluvia ácida', producen la formación de yeso.

fundamentalmente para los morteros de mayor relación aic'

\section{SUMMARY}

The reaction of portland cement mortars with $\mathrm{SO}_{2}$ gaseous pollutant and artificial 'acid rain' solution has been examined using laboratory exposure chambers, with realistic presentation rates of pollutants. The mortar were previously carbonated to produce superficial carbonation. Two mortars with different $w / c$ ratio and hence specific surface were prepared and exposed into the chambers.

For dry deposition of $\mathrm{SO}_{2}$ pollutant gas, the important roles of water and water plus oxidant in increasing chemical reaction are readily revealed. Further, accessible porosity also increases reaction through increased times of reaction of pollutant with the mortars. Interestingly, in the absence of deliberate surface wetting, the presence of oxidant, ozone, leads to a reduction in the already limited extent of reaction. Wei deposition studies using artificial 'acid rain' solution result in gypsum formation, which is more extensive for mortars of increased $w / c$ ratios.

\section{INTRODUCCIÓN}

En la última decada han sido numerosos los trabajos que han anarcido relacionando la contaminacion ambiental con cl deterioro de los matcriales pétreos de los edificios $(1,2)$

\section{INTRODUCTION}

Studies on the degradation of warious building stones by man-made pollutants have been reported relatively widely over the last decade $(1,2)$, with the many factors 
Los factores que producen el deterioro de estos materiales son numerosos y se pueden dividir en dos grupos generales:

(i) parámetros ambientales, tales como temperatura, humedad relativa, concentración de contaminante, etc.

(ii) propiedades físicas y químicas del material expuesto.

Los mecanismos de transferencia del contaminante a la superficie del material, se definen como "deposición" seca y "deposición" húmeda. Mientras que en la "deposición" seca son básicamente los contaminantes gaseosos los que producen el deterioro, en términos de "deposición" húmeda, las disoluciones de sales, como la "lluvia ácida", son los agentes agresivos que producen la degradación del material.

Los procesos medioambientales son complejos y, por tanto, son muchos los factores asociados con la degradación y el deterioro de los materiales. Con el fin de simplificar dichos estudios, se han desarrollado cámaras de laboratorio que simulan dichos ambientes. En estas cámaras, una variable o un grupo de variables, tales como adición de uno o varios gases contaminantes, pueden ser modificadas, mientras que las otras se mantienen constantes. Por ejemplo, para estudiar las variaciones de las propiedades físicas y químicas de los materiales de construcción producidas por la deposición seca, se han utilizado cámaras de laboratorio que simulan las velocidades de deposición reales en determinadas condiciones medioambientales. La mayoría de los estudios se han realizado sobre piedras calizas o silíceas (3-9), existiendo pocos trabajos relacionados con morteros de cemento (1012). Lewry y colaboradores (3) estudiaron la influencia que parámetros medioambientales tales como concentración de contaminante o la presencia de agua tenían en el deterioro de piedras calizas y dolomitas. Sus estudios indican que la concentración de contaminante no tiene tanta importancia como la presencia de agua. Para la caliza, la oxidación del $\mathrm{SO}_{2}$ en condiciones secas, es independiente de la concentración de contaminante. Sin embargo, en presencia de agua, la oxidación depende de la concentración de $\mathrm{SO}_{2}$, de manera que un aumento en la concentración de $\mathrm{SO}_{2}$ produce una mayor oxidación. Resultados similares se obtuvieron para piedras dolomitas. En ausencia de agua líquida, la disolución del $\mathrm{SO}_{2}(\mathrm{~g})$ en la película de humedad residual de la superficie del material, es la etapa controlante, donde incluso a elevadas concentraciones de $\mathrm{SO}_{2}(\mathrm{~g})$ la reacción es lenta. Sin embargo, en presencia de agua, la disolución de $\mathrm{SO}_{2}(\mathrm{~g})$ es una etapa rápida, por lo que en estas condiciones, sería la oxidación del $\mathrm{SO}_{2}$ (aq) la etapa controlante (4). influencing materials degradation being subdivided in two general groups as indicated below:

(i) atmospheric parameters, such as, relative humidity, temperature, pollutant concentration, etc.,

\section{(ii) physical and chemical properties of the exposed material.}

The mechanisms of transfer pollutants to material surfaces involve dry and wet deposition processes. For dry deposition, gaseous pollutants are basically involved in the degradation process, with the material surface having different wetnesses. In wet deposition, salt solutions, for instance 'acid rain', represent the aggressive medium for material degradation.

Weathering process are complex and many factors are associated with materials decay and degradation. In order to allow quantification of the various individual factors on materials decay, laboratory-based chambers have been used. In such chambers, a single factor or a group of factors, e.g. individual or combinations of pollutants, can be varied systematically while others are held constant. For example, laboratory-based atmospheric flow chambers, with realistic presentation rates of pollutants, similar to those outdoors, have been employed to examine the physical and chemical changes of building materials under dry deposition conditions. Many studies have used limestones and granites (3-9), with comparatively few related to concrete $(10,12)$. Lewry et al. (3) studied the influence of atmospheric parameters, including pollutant concentration and the presence of water, on the degradation of Portland limestone and dolomitic sandstone, with pollutant concentration not being considered to be as important factor as the presence of water. For Portland limestone, $\mathrm{SO}_{2}$ oxidation under dry conditions was almost independent of $\mathrm{SO}_{2}$ concentration; however, on wetted stones surfaces, $\mathrm{SO}_{2}$ oxidation increase as pollutant concentration increase. Similar results were obtained for dolomitic sandstone. In the absence of deliberately added water, $\mathrm{SO}_{2}(\mathrm{~g})$ dissolution in the residual moisture film on the stone surface, is the controlling step; thus, even at high $\mathrm{SO}_{2}$ (g) concentrations, the reaction is very limited.

However, in the presence of additional water, further $\mathrm{SO}_{2}(g)$ dissolution proceeds; oxidation is controlled by the presence of oxidant and catalytic species (4). 
Girardet y colaboradores (5) estudiaron la influencia que el tiempo de exposición tenía en el deterioro de diferentes materiales pétreos, observando, como era previsible, que se producía un mayor deterioro después de largos períodos de exposición. Girardert y Furlan (6) correlacionaron los datos obtenidos en las cámaras de simulación, con los datos obtenidos 'in situ' para diferentes materiales pétreos. Todos los materiales, excepto el mármol, presentaron buena correlación entre los datos del laboratorio y los datos 'in situ'. Es bien conocido que para el mármol, la deposición de gases contaminantes y su posterior reacción es un proceso más lento que para el resto de los materiales pétreos de naturaleza caliza. Ello es debido tanto a su baja porosidad, (1-3\%), como a la diferente forma cristalina del $\mathrm{CaCO}_{3}(6-8)$.

En este trabajo, morteros de cemento portland se han sometido a ambientes agresivos en el laboratorio. Dichos morteros han sido sometidos a un proceso de carbonatación acelerada para simular condiciones externas donde los materiales presentan una capa externa de carbonatación. El proceso de carbonatación del mortero produce la formación de $\mathrm{CaCO}_{3}$ de manera diferente a como se produce en la naturaleza en las piedras calizas, por lo que se estudiará la posible influencia de dicho parámetro en el comportamiento de los morteros en presencia de los contaminantes atmosféricos. En estudios previos (3-9) realizados sobre piedras, se ha determinado que la porosidad y la presencia de agua en el medio, juegan un papel importante en las reacciones de degradación, por lo que se estudiará la influencia de ambos parámetros en el deterioro de los morteros.

Con respecto a la deposición húmeda, son varios los tipos de ensayos utilizados. Por ejemplo, las muestras se sumergen continuamente en la disolución agresiva (10); debido al ataque químico de la disolución hacia la muestra, la concentración de dicha disolución debe ser cambiada con mucha frecuencia para mantener constantes las condiciones del ensayo. En otro de los ensayos, la disolución se rocía sobre las muestras, de manera que las condiciones experimentales no varían a lo largo del ensayo. Igual que para la deposición seca, el número de trabajos relacionados con la deposición húmeda en morteros de cemento, es escaso $(1,10,11)$. En este trabajo, se ha estudiado el efecto que produce en la degradación de los morteros de cemento, el rociado de las muestras con una fina lluvia de sulfatos en forma de "lluvia ácida", con adicionales ciclos humedad/secado.

\section{EXPERIMENTAL}

\section{Preparación de las muestras}

Se prepararon morteros de cemento (OPC), de dimensiones $5 \times 3 \times 0,5 \mathrm{~cm}$, con relación árido/ligante $3 / 1$,
Girardet et al. (5) examined the influence of time of exposure of different materials and, as expected, showed that degradation increased with exposure time. Good correlation between data from simulation chambers and outside exposure, other than for marble, was shown by Girardet and Furlan (6). For marble, there is general agreement that pollutant deposition and subsequent reaction are slower than for other carbonaceous materials; which are considered to result from the relatively low porosity (1-3\%) as well as the different crystalline form of $\mathrm{CaCO}_{3}(6-8)$.

In the present study, laboratory-based exposure of cement mortar has been undertaken. The cement mortar have been carbonated in order to simulate carbonated external surface. The formation of $\mathrm{CaCO}_{3}$ in cement mortar differs from limestone, and hence, contrasting behaviour in the presence of pollutant gases may be expected. From previous studies of petreous materials (3-9), porosity and the presence of water play important roles in the degradation reaction. Thus the influence of these parameters on the degradation of cement mortars has also been considered.

With regard to wet deposition studies, various different tests may be employed. For example, samples may be immersed continuously in solution (10); however, due to chemical reaction between the solution and sample, the solution must be replaced frequently to maintain the exposure conditions over the test duration. In other tests, salt solutions are sprayed over the samples, maintaining the same conditions over the test period. As for dry deposition, relatively few studies have considered the effects of wet deposition of pollutants on concrete $(1,10,11)$. Thus, here, sulphate in the form of a fine mist, present in artificial 'acid rain' solution, with wetting and drying cycles has been employed to examine its effects on the degradation of mortars.

\section{EXPERIMENTAL}

\section{Specimen preparation}

Cement (OPC) mortar specimens, of dimensions $5 \times 3 \times 0.5, \mathrm{~cm}$ were employed. A silica (99\% quartz) sand 
siendo el árido de naturaleza silícea (cuarzo de $99 \%$ de pureza). Se utilizaron dos relaciones agua/cemento $(\mathrm{a} / \mathrm{c})$ en la preparación de los morteros que fueron: 0,4 y 0,6.

La composición química del cemento portland y el árido utilizados en la preparación de los morteros se presentan en la tabla I.

Una vez preparadas y enmoldadas, las probetas se llevaron a una cámara que se encontraba al $50 \%$ de humedad relativa, desmoldándose a las 24 horas. Diariamente y durante un período de dos horas se adicionó $\mathrm{CO}_{2}$ a las probetas dentro de la cámara. Este proceso se repitió durante 28 días, al cabo de los cuales las muestras fueron guardadas en un desecador a temperatura ambiente.

Las muestras secas a $40^{\circ} \mathrm{C}$ y pesadas, se expusieron en las cámaras de deposición seca y húmeda de acuerdo a las condiciones presentadas en el siguiente apartado. Mediante porosimetría de mercurio, se determinó la porosidad total de las muestras antes de exponerlas en las cámaras.

\section{Deposición seca}

Las condiciones de trabajo de las cámaras en las que se expusieron las probetas se han descrito con anterioridad (4). Las condiciones de exposición en las cámaras se presentan en la tabla II. Como se indica en dicha tabla, la concentración del gas contaminante $\mathrm{SO}_{2}$ es de $7 \times 10^{-3}$ $\mathrm{mg} \mathrm{SO}_{2} / 1$ aire, a una humedad relativa del $84 \%$. La influencia del agua superficial se examinó añadiendo diariamente $8 \mathrm{ml}$ de agua durante 1 hora sobre la superficie de las muestras. Adicionalmente se estudió la influencia del ozono como oxidante, mezclando $8 \times 10^{-3}$ $\mathrm{mg} \mathrm{O}_{3} / 1$ aire con el aire y contaminante en las condiciones indicadas anteriormente. El flujo de aire adicionado a las cámaras 1 y 4 fue de 21 aire/min., mientras que en las cámaras las cámaras 2 y 3 fue de 51 aire/min. El tiempo de exposición de los morteros en las cámaras fue, en todos los casos, de 8 semanas.

\section{Análisis}

Una vez terminada la exposición, las muestras fueron secadas a $40^{\circ} \mathrm{C}$ y analizadas por DRX y FTIR.

Durante la exposición, diariamente se recogieron los líquidos de lavado superficial de las muestras, que se analizaron semanalmente. Los aniones $\mathrm{SO}_{3}{ }^{2-}$ y $\mathrm{SO}_{4}{ }^{2-}$ se analizaron por cromatografia líquida (HPLC). En general la concentración de iones $\mathrm{SO}_{3}{ }^{2-}$ fue muy pequeña en comparación con la concentración de iones $\mathrm{SO}_{4}{ }^{2-0} \mathrm{O}$ incluso nula. La concentración de los elementos $\mathrm{Ca}, \mathrm{K}$ y Si presentes en la disolución se determinaron por absorción atómica. to cement ratio of $3 / 1$ was used. Two water/cement ratios, 0.4 and 0.6 , were employed to prepare the mortars.

Chemical composition of the portland cement and the sand are given in table $I$.

After moulding, the samples were placed in a chamber at $50 \%$ relative humidity and, after curing for 24 hours, the specimens were removed from the moulds and subjected to daily $\mathrm{CO}_{2}$ addition for 2 hours over a 28 day period. Finally, the samples were stored in a desiccator, at room temperature, until required.

Prior to exposure in the rigs, the samples were dried at $40^{\circ} \mathrm{C}$ for $24 \mathrm{~h}$. Weighed samples were exposed to the dry and wet deposition of pollutants, under conditions given in the following sections. The total porosity of unexposed, individual samples was determined by mercury porosimetry.

\section{Dry deposition}

The laboratory-based rigs for the dry deposition of pollutants have been described elsewhere (4); typical pollutant concentrations utilised in individual chambers are given in table II. As indicated in the table, $\mathrm{SO}_{2}$ gaseous pollutant at a concentration of $7 \times 10^{-3} \mathrm{mg} \mathrm{SO} / \mathrm{l}$ air flow was used at a relative humidity of $84 \%$. The influence of additional surface water was also examined, with $8 \mathrm{ml}$ of water passing over the mortar surface for 1 hour every day. Further, the influence of ozone as oxidant, at a concentration of $8 \times 10^{-3} \mathrm{mg} \mathrm{O}_{3} / \mathrm{l}$ air flow, was examined for mortars exposed at $84 \%$ relative humidity and those additionally wetted with water. The air flow in chambers 1 and 4 was $2 \mathrm{l}$ air $/ \mathrm{min}$, whereas that in chambers 2 and 3 was 5 lairimin. The exposure time in all the chambers was 8 weeks.

\section{Analyses}

After exposured of the samples, they were dried at $40^{\circ} \mathrm{C}$ and analysed by XRD and FTIR.

During exposure, the daily run-off was collected and $\mathrm{SO}_{3}^{2-}$ and $\mathrm{SO}_{4}^{2-}$ concentration determined on a weekly basis by $\mathrm{HPLC}$. Generally, $\mathrm{SO}_{3}{ }^{2-}$ anion concentration was very low relative to $\mathrm{SO}_{4}^{2-}$ concentration or absence. The $\mathrm{Ca}, \mathrm{K}$ and Si elements contents of the respective solutions were determined by atomic absorption. After 8 
TABLA I (TABLE I)

Composición química del cemento y el árido

(Chemical composition of cement and sand)

\begin{tabular}{|c|c|c|}
\hline $\begin{array}{c}\text { Oxido } \\
\text { (Oxide) }\end{array}$ & $\begin{array}{c}\text { Cemento } \\
\text { (Cement) }\end{array}$ & $\begin{array}{c}\text { Árido } \\
\text { (Sand) }\end{array}$ \\
\hline & $20,67 \%$ & $98,92 \%$ \\
$\mathrm{SiO}_{2}$ & $4,31 \%$ & $0,18 \%$ \\
$\mathrm{Al}_{2} \mathrm{O}_{3}$ & $3,39 \%$ & $0,06 \%$ \\
$\mathrm{Fe}_{2} \mathrm{O}_{3}$ & $65,10 \%$ & $0,00 \%$ \\
$\mathrm{CaO}$ & $2,70 \%$ & $0,28 \%$ \\
$\mathrm{MgO}$ & $2,89 \%$ & $0,00 \%$ \\
$\mathrm{SO}$ & $1,18 \%$ & $0,05 \%$ \\
L.I. & $0,27 \%$ & $0,40 \%$ \\
R.I. & \multicolumn{2}{|l}{} \\
\hline
\end{tabular}

TABLA \| (TABLE //)

Condiciones de exposición en cámaras de gases

(Exposure conditions for dry deposition studies)

\begin{tabular}{|c|c|c|c|c|}
\hline $\begin{array}{c}\text { Cámara } \\
\text { (chamber) }\end{array}$ & $\begin{array}{l}\mathrm{mg} \mathrm{SO} \\
\text { (mg aire } \\
(\mathrm{mg} \mathrm{SO} / / \text { air })\end{array}$ & $\begin{array}{l}\mathrm{mg} \mathrm{O}_{3} / \mathrm{l} \text { aire } \\
\left(\mathrm{mg} \mathrm{O} \mathrm{O}_{3} / / \text { air }\right)\end{array}$ & $\begin{array}{l}\mathrm{ml} \mathrm{H}_{2} \mathrm{O} / \mathrm{l} \text { aire } \\
\text { ( } \mathrm{ml} \mathrm{H} \mathrm{H}_{2} \mathrm{O} / \mathrm{l} \text { air) }\end{array}$ & $\begin{array}{l}\mathrm{mg} \mathrm{SO} \mathrm{SO}_{2} \cdot \mathrm{cm}^{-2} \cdot \mathrm{s}^{-1} \\
\left(\mathrm{mg} \mathrm{SO} \mathrm{SO}_{2} \cdot \mathrm{cm}^{-2} \cdot \mathrm{s}^{-1}\right)\end{array}$ \\
\hline $\begin{array}{l}1 \\
2 \\
3 \\
4\end{array}$ & $\begin{array}{l}7 \times 10^{-3} \\
7 \times 10^{-3} \\
7 \times 10^{-3} \\
7 \times 10^{-3}\end{array}$ & $\begin{array}{l}8 \times 10^{-3} \\
8 \times 10^{-3}\end{array}$ & $\begin{array}{l}70 \times 10^{-3} \\
70 \times 10^{-3}\end{array}$ & $\begin{array}{l}3,6 \times 10^{-6} \\
9,9 \times 10^{-6} \\
9,9 \times 10^{-6} \\
3,6 \times 10^{-6}\end{array}$ \\
\hline
\end{tabular}

Después de las 8 semanas de exposición, se determinaron las sales solubles en agua y retenidas en el mortero y sobre ellas se analizaron los aniones $\mathrm{SO}_{4}{ }^{2-}$ y $\mathrm{SO}_{3}{ }^{2-}$.

\section{Deposición húmeda}

Muestras curadas en las condiciones especificadas anteriormente fueron expuestas en la cámara de rociado de disoluciones, utilizando "lluvia ácida" como disolución agresiva. La composición de la disolución es la siguiente:

$31,8 \mathrm{mg} \mathrm{H}_{2} \mathrm{SO}_{4}(98 \%) / / ; 15,7 \mathrm{mg} \mathrm{HNO}(70 \%) / / ; 46,2 \mathrm{mg}$ $\left(\mathrm{NH}_{4}\right)_{2} \mathrm{SO}_{4} / l ; 31,9 \mathrm{mg} \mathrm{Na}_{2} \mathrm{SO}_{4} / / 21,2 \mathrm{mg} \mathrm{NaNO} / / ; 84,8 \mathrm{mg}$ $\mathrm{NaCl} / /$, ajustándose el pH a 3,5 adicionando $\mathrm{NaHCO}_{3}$. Dicha concentración es diez veces superior a la de la ciudad del área del Greater Manchester.

Las condiciones de exposición fueron en ciclos de humedad/secado; 2 horas rociando la disolución, seguido por dos horas de secado a $35^{\circ} \mathrm{C}$. La disolución se roció a un flujo de $0,5 \mathrm{l} / \mathrm{h}$, y el tiempo de exposición fue de 4 semanas. Después de 4 semanas de exposición las muestras se secaron a $40^{\circ} \mathrm{C}$ y se determinó la variación de peso que habían experimentado. Los cambios estructurales weeks exposure, soluble salts, retained in the dried mortar, were extracted with water and $\mathrm{SO}_{3}{ }^{2-}$ and $\mathrm{SO}_{4}{ }^{2-}$ anion analysis, were undertaken.

\section{Wet deposition}

The mortar samples were placed in a salt spray cabinet using an artificial 'acid rain' solution of composition:

$31.8 \mathrm{mg} \mathrm{H} \mathrm{HO}_{4}(98 \%) / \mathrm{l}, 15.7 \mathrm{mg} \mathrm{HNO}(70 \%) / l, 46.2 \mathrm{mg}$ ( $\mathrm{NH}_{\mathrm{j}} \mathrm{SO}_{\mathrm{fl}} \mathrm{ll}, 31.9 \mathrm{mg} \mathrm{Na} \mathrm{SO}_{2} \mathrm{ll}, 21.2 \mathrm{mg} \mathrm{NaNO} / \mathrm{ll}, 84.8$ $\mathrm{mg} \mathrm{NaCl/l}$ with the $\mathrm{pH}$ adjusted to 3.5 with $\mathrm{NaHCO}_{3}$. The concentrations are ten times those of the average 'acid rain' falling in the Greater Manchester area.

The exposure regime involved dry and wet cycling, with spraying of the 'acid rain' solution as a fine mist for $2 \mathrm{~h}$ followed by drying at $35^{\circ} \mathrm{C}$ for $2 \mathrm{~h}$. A solution flow rate of $0.5 \mathrm{l} / \mathrm{h}$ was employed, with an exposure time of 4 weeks. After exposure, the samples were dried at $40{ }^{\circ} \mathrm{C}$ and weight changes determined. Additionally, any 
producidos en las muestras se examinaron por SEM/EDAX, FTIR y DRX.

\section{RESULTADOS Y DISCUSIÓN}

\section{Observaciones generales}

Experimentalmente se observó que las muestras con relación $\mathrm{a} / \mathrm{c}=0,4$, absorbían el agua que se les adicionaba diariamente, más rápidamente que los morteros $a / c=0,6$, $y$, por lo tanto, la cantidad de agua recogida en los líquidos de lavado superficial era menor en el caso de los morteros $\mathrm{a} / \mathrm{c}=0,4$ que en el de los de relación 0,6 .

Otro hecho observado experimentalmente, fue que a las 5 semanas de exposición en $\mathrm{SO}_{2}+\mathrm{O}_{3}+\mathrm{H}_{2} \mathrm{O}$, en las muestras con relación $\mathrm{a} / \mathrm{c}=0,4$ empezaron a aparecer depósitos blancos y marrones. Sin embargo, en las muestras con relación $\mathrm{a} / \mathrm{c}=0,6$ fueron necesarias 7 semanas antes de que aparecieran los mismos depósitos. En el caso de las muestras expuestas en las condiciones de adición de gas contaminante y agua $\left(\mathrm{SO}_{2}+\mathrm{H}_{2} \mathrm{O}\right)$, se pueden observar zonas de lavado del agua adicionada.

\section{Caracterización de los morteros}

Se determinó la porosidad total de las muestras por porosimetría de mercurio. Para los morteros con relación $\mathrm{a} / \mathrm{c}=0,4$, la porosidad fue del $35 \%$, con un $99 \%$ de poros de $100 \mu \mathrm{m}$ de diámetro. Un valor similar, $31 \%$, se obtuvo para los morteros con relación $\mathrm{a} / \mathrm{c}=0,6$. Sin embargo, en este caso, el tamaño de los poros es inferior, con un $50 \%$ de poros de $100 \mu \mathrm{m}$ de diámetro y el otro $50 \%$ de los poros de $4 \mu \mathrm{m}$ de diámetro de tamaño. Es conocido que el proceso de curado y enmoldado de los morteros juega un papel importante en la porosidad de las muestras. En este caso, debido al pequeño espesor de las muestras, no se compactaron. Por otra parte, se observó que ambas mezclas, pero especialmente la de relación $\mathrm{a} / \mathrm{c}=0,4$ estaban relativamente secas; observándose cierta exudación superficial del árido, produciéndose cierta modificación en la rugosidad superficial de las muestras. Dichas observaciones pueden explicar, en cierto modo, las diferencias microestructurales observadas.

La composición mineralógica de las muestras se determinó por FTIR. Las figuras 1 y 2 muestran dichos espectros para ambas muestras. En general, antes de la exposición, los dos espectros muestran bandas de absorción a 1.420 y $873 \mathrm{~cm}^{-1}$ debidas a vibraciones de los grupos $\mathrm{CO}_{3}{ }^{2-}$ de la calcita. $\mathrm{El}$ espectro del mortero $\mathrm{a} / \mathrm{c}=0,4$ presenta además bandas a 1.470 y $858 \mathrm{~cm}^{-1}$ debidos a las vibraciones del grupo $\mathrm{CO}_{3}{ }^{2-}$ presente en el aragonito. Los espectros presentan una banda ancha a $1.080 \mathrm{~cm}^{-1}$ que junto al doblete a 793 y $776 \mathrm{~cm}^{-1}$ indican la presencia de cuarzo procedente del árido del mortero. Una banda ancha sobre $1.000 \mathrm{~cm}^{-1}$ se debe a las compositional and structural changes of the mortars, if any, were probed by SEM/EDX, FTIR and XRD.

\section{RESULTS AND DISCUSSION}

\section{General observations}

Over the period of the dry deposition runs, it was observed that water was absorbed rapidly, after daily addition, for the mortar with $w / c$ ratio of 0.4 compared with the mortars of $w / c$ ratio of 0.6 . Consequently, the volume of run-off collected for mortars with the lower $w / c$ ratio was significantly less than that from mortars with $w / c$ ratio of 0.6 .

It was also observed that, after exposure to $\mathrm{SO}_{2}+\mathrm{O}_{3}+\mathrm{H}_{2} \mathrm{O}$ for 5 weeks, mortar samples of $w / c=0.4$ showed light brown and white deposits over the sample surface; however, for mortars of $w / c=0.6$, increased exposure for 7 weeks was necessary for visual revelation of similar deposits. In the case of the samples exposed to $\mathrm{SO}_{2}+\mathrm{H}_{2} \mathrm{O}$ no deposit were revealed in the wetted region of the stone.

\section{Mortar characterisation}

The total porosity of the samples was determined by mercury porosimetry. For mortars with $w / c=0.4$, the bulk porosity was $35 \%$ with $99 \%$ of the pores having diameter of $100 \mu \mathrm{m}$. A similar bulk porosity, 31\%, was determined for mortars with $w / c=0.6$. However, such mortars have reduced pore dimensions, with 50\% about 100 um diameter and 50\% about 4 rm diameter. It is well known that mortar moulding and curing prior to hardening play important roles in the final porosity of the samples. In the present case, due to the relatively low thickness of the samples, compaction was not undertaken. In addition, it was evident that both mixtures were relatively dry, particularly for the mortar of $w / c=0.4$, where some exudation of the sand was also observed, resulting in variation of surface roughness of the respective mortars. Overall different microestructural can be explained.

Mineralogical composition of the samples was determined by FTIR, with the spectra for mortars of $w / c=0.4$ and 0.6 given in figures 1 and 2 respectively. In general, before exposure, the spectra are similar, with absorption bands at 1.420 and $873 \mathrm{~cm}^{-1}$ arising from $\mathrm{CO}_{3}^{2-}$ vibrations form calcite. Mortars of $w / c=0.4$ unlike those of $w / c=0.6$, showed peaks at 1.470 and $858 \mathrm{~cm}^{-1}$, which arise from $\mathrm{CO}_{3}^{2-}$, i.e. aragonite. The broad band at $1.080 \mathrm{~cm}^{-1}$, together with the sharp doublet at 793 and $776 \mathrm{~cm}^{-1}$, arises from quartz from the sand. The broad band at $1.000 \mathrm{~cm}^{-1}$ originates from $\mathrm{Si}-\mathrm{O}$ from $C-S$ - $H$ gel formation during hydration of the cement. Additionally, the shoulders at 1.157 and $1.136 \mathrm{~cm}^{-1}$ 


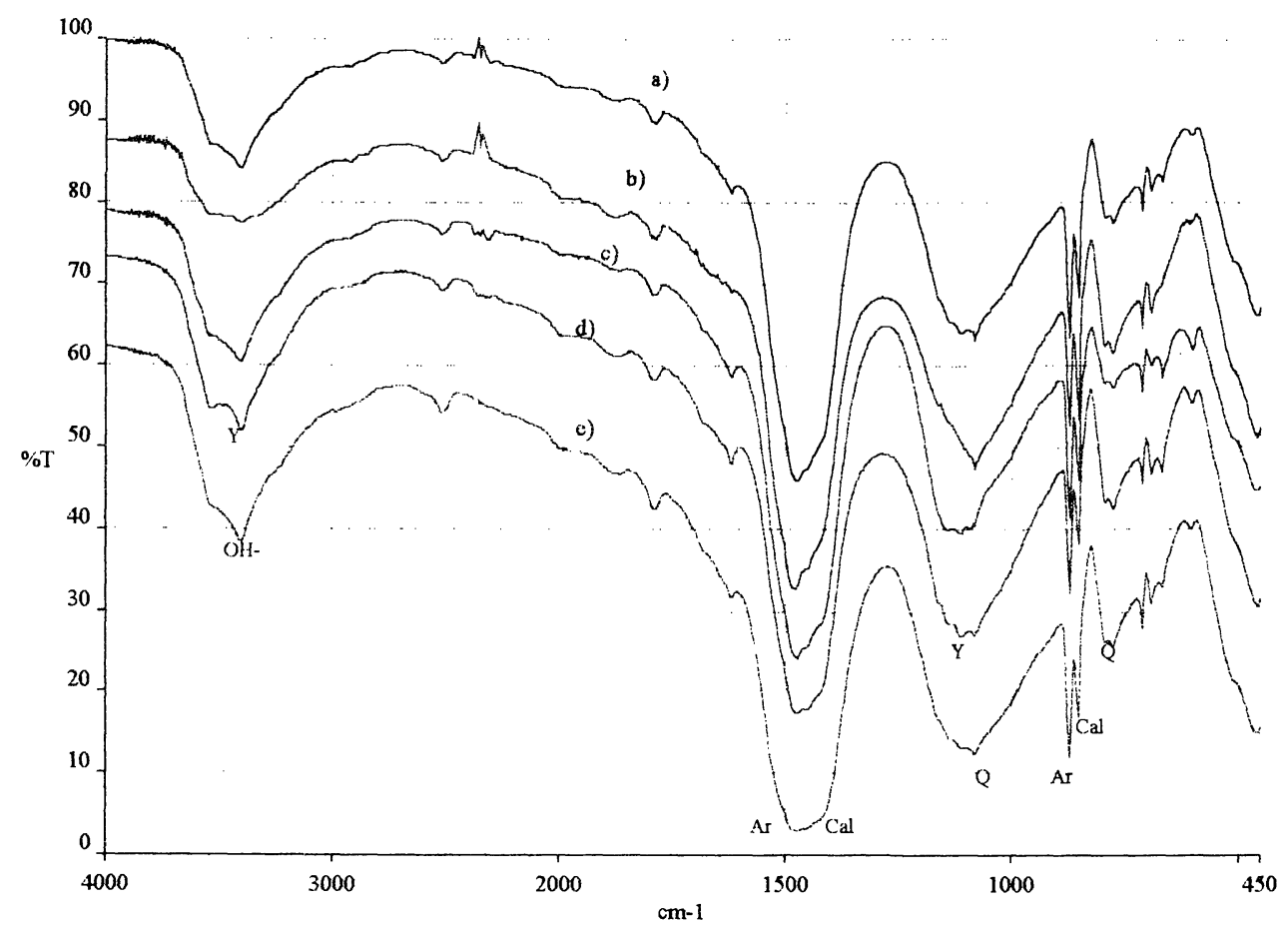

Fig. l.- Espectros FTIR de morteros a/c $=0,4$ expuestos en diferentes condiciones: a) $\mathrm{SO}_{2}$; b) $\mathrm{SO}_{2}+\mathrm{O}_{3}$; c) $\mathrm{SO}_{2}+\mathrm{H}_{2} \mathrm{O}$; d) $\mathrm{SO}_{2}+\mathrm{O}_{3}+\mathrm{H}_{2} \mathrm{O}$; e) $\sin$ exponer. Fig. I.- FTIR spectra of $\mathrm{w} / \mathrm{c}=0,4$ ratio mortar under different exposure conditions: a) $\mathrm{SO}_{2} ;$ b) $\mathrm{SO}_{2}+\mathrm{O}_{3} ;$ c) $\mathrm{SO}_{2}+\mathrm{H}_{2} \mathrm{O} ;$ d) $\mathrm{SO}_{2}+\mathrm{O}_{3}+\mathrm{H}_{2} \mathrm{O}$; e) unexposed.

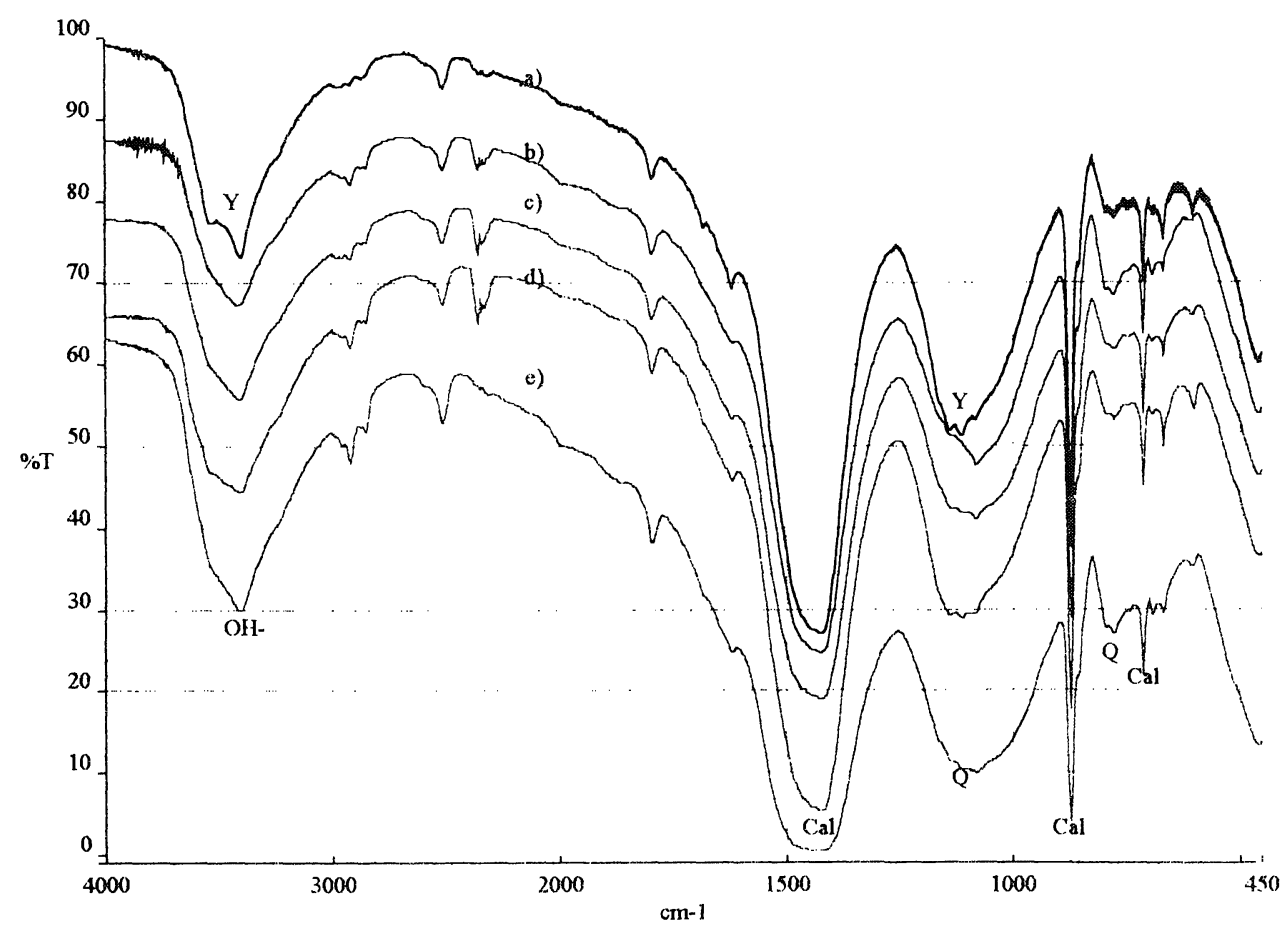

Fig. 2.- Espectros FTIR de morteros a/c $=0,6$ expuestos en diferentes condiciones: a) $\left.\left.\left.\mathrm{SO}_{2} ; \mathrm{b}\right) \mathrm{SO}_{2}+\mathrm{O}_{3} ; \mathrm{c}\right) \mathrm{SO}_{2}+\mathrm{H}_{2} \mathrm{O} ; \mathrm{d}\right) \mathrm{SO}_{2}+\mathrm{O}_{3}+\mathrm{H}_{2} \mathrm{O} ; \mathrm{e}$ ) sin exponer. Fig. 2.- FTIR spectra of $w / c=0,6$ ratio mortar under different exposure conditions: a) $\mathrm{SO}_{2}$; b) $\mathrm{SO}_{2}+\mathrm{O}_{3} ;$ c) $\mathrm{SO}_{2}+\mathrm{H}_{2} \mathrm{O}_{2}$ d d $\mathrm{SO}_{2}+\mathrm{O}_{3}+\mathrm{H}_{2} \mathrm{O}_{i}$ e) unexposed. 
vibraciones del grupo Si-O del gel C-S-H formado en el proceso de hidratación del cemento. Adicionalmente, pequeños hombros a 1.157 y $1.136 \mathrm{~cm}^{-1}$ indican la presencia de yeso en pequeñas cantidades en la muestra inicial; un pequeño hombro a $1.115 \mathrm{~cm}^{-1}$, indica la presencia de ettringita en poca cantidad debido al bajo grado de hidratación del cemento.

\section{Deposición seca}

Se determinó la concentración de iones sulfato presente en los líquidos de lavado superficial de las muestras expuestas en ambientes con adición de $\mathrm{SO}_{2}$. Conociendo el tamaño de las muestras, el área expuesta y el tiempo de exposición, se calcularon los $\mathrm{mg} \mathrm{SO}_{2} \cdot \mathrm{cm}^{-2} \cdot \mathrm{s}^{-1} \mathrm{y}$ el porcentaje de conversión del $\mathrm{SO}_{2} \mathrm{a} \mathrm{SO}_{4}^{2-}$ de los morteros expuestos en las cámaras. Dichos valores se resumen en las tablas III y IV para los morteros con relación $\mathrm{a} / \mathrm{c}=0,4$ y en las tablas $\mathrm{V}$ y VI para los morteros con relación $\mathrm{a} / \mathrm{c}=0,6$. Cada valor es la media de dos muestras.

De los resultados presentados en las tablas III-VI, es evidente que el porcentaje de conversión de $\mathrm{SO}_{2}$ a sulfato es mayor para las muestras expuestas en presencia conjunta de oxidante y agua. En general, la tendencia de crecimiento es similar para los dos morteros. En la cámara con adición de agua, especialmente en presencia de oxidante, el porcentaje de conversión de $\mathrm{SO}_{2}$ a sulfatos aumenta cuando la relación a/c disminuye. Ello se atribuye a un aumento en el confirm the presence of small amounts of gypsum in the initial sample. Finally a small shoulder at $1.115 \mathrm{~cm}^{-1}$ arising from ettringite due to the low hydration degree of the cement.

\section{Dry deposition studies}

For the mortar exposed to $\mathrm{SO}_{2}$ pollutant gas, sulphate concentrations in run-off from the wetted samples were determined. Further with knowledge of the samples dimensions, and the concentration of $\mathrm{SO}_{2}$ flowing through the chamber over the exposure period, sulphate concentrations can be transformed to $\mathrm{mg} \mathrm{SO} \mathrm{Cm}^{-2} \cdot \mathrm{s}^{-1}$ and the percentage conversion of $\mathrm{SO}_{2}$ to sulphate calculated. These values are summarised in tables III and $I V$ for mortars of $w / c=0.4$ and tables $V$ and VI for mortars of $w / c=0.6$. Each value is the average from two samples.

From tables III-VI, considering exposure for 8 weeks, it is evident that the percentage conversion of $\mathrm{SO}_{2}$ to sulphate increased with wetted samples exposed to oxidant. Generally, a similar trend is evident for both mortars, i.e., independent of the $w / c$ ratio.

For the wetted mortars, particularly in the presence of oxidant, the percentage conversion of $\mathrm{SO}_{2}$ to sulphate increased as the $w / c$ ratio decreased. This is attributed to the increased pore diameter, i.e. $100 \mu \mathrm{m}$ for mortars

TABLA III (TABLE III)

Concentración de sulfatos en los líquidos de lavado superficial en términos de $\mathrm{ppm}$ y $\mathrm{mg} \mathrm{SO}_{2} \cdot \mathrm{cm}^{-2} \cdot \mathrm{s}^{-1}$ y porcentaje de conversión de $\mathrm{SO}_{2}$ a sulfato para los morteros con relación a/c $=0,4$ expuestos en $\mathrm{SO}_{2}+\mathrm{H}_{2} \mathrm{O}$.

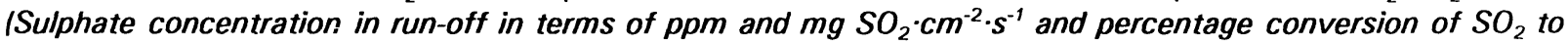
sulphate for mortar of $w / C=0.4$ exposed to $\mathrm{SO}_{2}+\mathrm{H}_{2} \mathrm{O}$ )

\begin{tabular}{|c|c|c|c|}
\hline $\begin{array}{c}\text { Tiempo(Time) } \\
\text { semanas/weeks) }\end{array}$ & $\begin{array}{c}{\left[\mathbf{S O}_{\mathbf{4}}{ }^{2}\right]_{\text {run-oft }}} \\
(\mathbf{p p m})\end{array}$ & $\mathrm{mg} \mathrm{SO}_{\mathbf{2}} \cdot \mathbf{c m}^{-2} \cdot \mathbf{s}^{-1}$ & $\begin{array}{c}\text { porcentaje conversión (\%) } \\
\text { percentage conversion (\%) }\end{array}$ \\
\hline $\mathbf{1}$ & 42,3 & $8,5 \times 10^{-8}$ & 0,9 \\
$\mathbf{2}$ & 77,0 & $15,5 \times 10^{-8}$ & 1,6 \\
$\mathbf{3}$ & 87,3 & $17,6 \times 10^{-8}$ & 1,8 \\
$\mathbf{4}$ & 94,2 & $19,0 \times 10^{-8}$ & 1,9 \\
$\mathbf{5}$ & 97,6 & $19,7 \times 10^{-8}$ & 2,0 \\
$\mathbf{6}$ & 100,9 & $20,4 \times 10^{-8}$ & 2,1 \\
$\mathbf{7}$ & 104,7 & $21,1 \times 10^{-8}$ & 2,1 \\
$\mathbf{8}$ & 107,8 & $21,7 \times 10^{-8}$ & 2,9 \\
\hline
\end{tabular}


Concentración de sulfatos en los líquidos de lavado superficial en términos de ppm y $\mathrm{mg} \mathrm{SO} \mathrm{SO}_{2} \cdot \mathrm{cm}^{-2} \cdot \mathrm{s}^{-1}$ y porcentaje de conversión de $\mathrm{SO}_{2}$ a sulfato para los morteros con relación a/c $=0,4$ expuestos en

$$
\mathrm{SO}_{2}+\mathrm{H}_{2} \mathrm{O}+\mathrm{O}_{3} \text {. }
$$

(Sulphate concentration in run-off in terms of ppm and $\mathrm{mg} \mathrm{SO} \mathrm{S}_{2} \cdot \mathrm{cm}^{-2} \cdot \mathrm{s}^{-1}$ and percentage conversion of $\mathrm{SO}_{2}$ to sulphate for mortar of $\mathrm{w} / \mathrm{c}=0.4$ exposed to $\mathrm{SO}_{2}+\mathrm{H}_{2} \mathrm{O}+\mathrm{O}_{3}$ )

\begin{tabular}{|c|c|c|c|}
\hline $\begin{array}{c}\text { Tiempo(Time) } \\
\text { (semanas)(weeks) }\end{array}$ & $\begin{array}{c}\left.\text { [SO }_{4}{ }^{2} \cdot\right]_{\text {run-oft }} \\
\text { (ppm) }\end{array}$ & $\mathbf{m g ~ S O}_{\mathbf{2}} \cdot \mathbf{c m}^{-2} \cdot \mathbf{s}^{-1}$ & $\begin{array}{c}\text { porcentaje conversión (\%) } \\
\text { percentage conversion (\%) }\end{array}$ \\
\hline $\mathbf{1}$ & 53,2 & $1,1 \times 10^{-7}$ & 3,1 \\
$\mathbf{2}$ & 94,2 & $1,9 \times 10^{-7}$ & 3,1 \\
$\mathbf{3}$ & 151,7 & $3,1 \times 10^{-7}$ & 8,7 \\
$\mathbf{4}$ & 209,9 & $4,2 \times 10^{-7}$ & 11,8 \\
$\mathbf{5}$ & 258,0 & $5,2 \times 10^{-7}$ & 14,6 \\
$\mathbf{6}$ & 313,9 & $6,3 \times 10^{-7}$ & 17,6 \\
$\mathbf{7}$ & 369,5 & $7,5 \times 10^{-7}$ & 21,0 \\
$\mathbf{8}$ & 440,2 & $8,9 \times 10^{-7}$ & 24,9 \\
\hline
\end{tabular}

\section{TABLA V (TABLE V)}

Concentración de sulfatos en los líquidos de lavado superficial en términos de $\mathrm{ppm} \mathrm{y} \mathrm{mg} \mathrm{SO} \mathrm{SO}_{2} \cdot \mathrm{cm}^{-2} \cdot \mathrm{s}^{-1}$ y porcentaje de conversión de $\mathrm{SO}_{2}$ a sulfato para los morteros con relación a/c $=0,6$ expuestos en

$$
\mathrm{SO}_{2}+\mathrm{H}_{2} \mathrm{O} \text {. }
$$

(Sulphate concentration in run-off in terms of ppm and $\mathrm{mg} \mathrm{SO} \mathrm{S}_{2} \cdot \mathrm{cm}^{-2} \cdot \mathrm{s}^{-1}$ and percentage conversion of $\mathrm{SO}_{2}$ to sulphate for mortar of $\mathrm{W} / \mathrm{c}=0.6$ exposed to $\mathrm{SO}_{2}+\mathrm{H}_{2} \mathrm{O}$ )

\begin{tabular}{|c|c|c|c|}
\hline $\begin{array}{c}\text { Tiempo(Time) } \\
\text { (semanas)(weeks) }\end{array}$ & $\begin{array}{c}{\left[\mathrm{SO}_{\mathbf{4}}{ }^{2}\right]_{\text {run-off }}} \\
\text { (ppm) }\end{array}$ & $\mathbf{m g ~ S O}_{\mathbf{2}} \mathbf{c m}^{-2} \cdot \mathbf{s}^{-1}$ & $\begin{array}{c}\text { porcentaje conversión (\%) } \\
\text { percentage conversion (\%) }\end{array}$ \\
\hline $\mathbf{1}$ & 3,0 & $6,0 \times 10^{-9}$ & 0,1 \\
$\mathbf{2}$ & 5,4 & $10,1 \times 10^{-9}$ & 0,1 \\
$\mathbf{3}$ & 7,2 & $14,5 \times 10^{-9}$ & 0,1 \\
$\mathbf{4}$ & 10,4 & $21,0 \times 10^{-9}$ & 0,2 \\
$\mathbf{5}$ & 14,5 & $29,3 \times 10^{-9}$ & 0,3 \\
$\mathbf{6}$ & 18,2 & $36,7 \times 10^{-9}$ & 0,4 \\
$\mathbf{7}$ & 21,8 & $44,0 \times 10^{-9}$ & 0,4 \\
$\mathbf{8}$ & 25,3 & $51,1 \times 10^{-9}$ & 0,5 \\
\hline
\end{tabular}

\section{TABLA VI (Table VI)}

Concentración de sulfatos en los líquidos de lavado superficial en términos de ppm y $\mathrm{mg} \mathrm{SO} \mathrm{SO}_{2} \cdot \mathrm{cm}^{-2} \cdot \mathrm{s}^{-1}$ y porcentaje de conversión de $\mathrm{SO}_{2}$ a sulfato para los morteros con relación a/c $=0,6$ expuestos en $\mathrm{SO}_{2}+\mathrm{O}_{3}+\mathrm{H}_{2} \mathrm{O}$.

(Sulphate concentration in run-off in terms of ppm and $\mathrm{mg} \mathrm{SO} \mathrm{S}_{2} \cdot \mathrm{cm}^{-2} \cdot \mathrm{s}^{-1}$ and percentage conversion of $\mathrm{SO}_{2}$ to sulphate for mortar of $\mathrm{W} / \mathrm{c}=0.6$ exposed to $\mathrm{SO}_{2}+\mathrm{O}_{3}+\mathrm{H}_{2} \mathrm{O}$ )

\begin{tabular}{|c|c|c|c|}
\hline $\begin{array}{c}\text { Tiempo(Time) } \\
\text { (semanas)(weeks) }\end{array}$ & $\begin{array}{c}\left.\mathbf{S O}_{4}{ }^{2}\right]_{\text {run-off }} \\
(\mathbf{p p m})\end{array}$ & $\mathbf{m g ~ S O}_{\mathbf{2}} \mathrm{cm}^{-2} \mathbf{s}^{-1}$ & $\begin{array}{c}\text { porcentaje conversión (\%) } \\
\text { (percentage conversion (\%)) }\end{array}$ \\
\hline $\mathbf{1}$ & 49,6 & $1,0 \times 10^{-7}$ & 2.8 \\
$\mathbf{2}$ & 79,2 & $1,6 \times 10^{-7}$ & 4,5 \\
$\mathbf{3}$ & 123,6 & $2,5 \times 10^{-7}$ & 7,0 \\
$\mathbf{4}$ & 151,8 & $3,1 \times 10^{7}$ & 8,7 \\
$\mathbf{5}$ & 188,3 & $3,8 \times 10^{-7}$ & 10,6 \\
$\mathbf{6}$ & 213,8 & $4,3 \times 10^{-7}$ & 12,0 \\
$\mathbf{7}$ & 228,1 & $4,6 \times 10^{-7}$ & 13,4 \\
$\mathbf{8}$ & 236,2 & $4,8 \times 10^{-7}$ & \\
\hline
\end{tabular}


diámetro de los poros, $100 \mu \mathrm{m}$ para los morteros con menor relación $\mathrm{a} / \mathrm{c}(\mathrm{a} / \mathrm{c}=0,4)$. Por lo tanto los morteros tienen una mayor capacidad de absorber agua, dato confirmado por la menor recogida de líquido de lavado superficial, que produciría que las probetas están mayor tiempo en contacto con el agua, lo que podría favorecer la reacción. Resultados similares fueron obtenidos por Henriksen (9) que estudió el efecto del $\mathrm{SO}_{2}$ sobre diferentes calizas y mármoles. Observó que la caliza de Vincenza que tenía una porosidad superior, y por tanto una mayor superficie expuesta, experimentaba mayor deterioro.

Después de las ocho semanas de exposición en las cámaras, se determinaron las sales solubles en agua. Dichos valores se añadieron a la concentración presente en los líquidos de lavado superficial y se determinó el porcentaje total de conversión de $\mathrm{SO}_{2}$ a sulfatos (Tablas VII y VIII). Estas tablas nos revelan la importancia de la presencia de agua en la reacción del $\mathrm{SO}_{2}$ con el mortero de cemento, especialmente en presencia de ozono como of $w / c=0.4$. Consequently, the mortars have an increased capacity of water adsorption, confirmed by the reduced level of run-off collection, and increased time of wetness and hence reaction. Such features were also observed by Henriksen (9) in a study of $\mathrm{SO}_{2}$ deposition on stones, where $\mathrm{SO}_{2}$ absorption was greater on the more porous Vincenza limestone than for other limestones.

After 8 weeks exposure, retained soluble salts, in the variously exposed mortars, were determined after extraction into water. The values were added to run-off concentrations, where appropriate, and the total percentage conversion of $\mathrm{SO}$, to sulphate determined (Table VII and VIII). From the Tables, the importance of water in the reaction of $\mathrm{SO}_{2}$ with cement mortar is again revealed, particularly with the additional

\section{TABLA VII (TABLE VII)}

Concentración de sulfatos en las sales solubles y en los líquidos de lavado superficial; porcentaje de conversión del $\mathrm{SO}_{2}$ a sulfatos para los morteros a/c $=0,4$ al cabo de 8 semanas de exposición

Sulphate concentration in soluble salts and run-off; percentage of $\mathrm{SO}_{2}$ conversion for mortar of $w / c=0.4$ after 8 weeks exposure

\begin{tabular}{|c|c|c|c|}
\hline $\begin{array}{l}\text { Condiciones de } \\
\text { exposición } \\
\text { (Exposure } \\
\text { conditions) }\end{array}$ & $\begin{array}{l}{\left[\mathrm{SO}_{4}{ }^{2-}\right]_{\mathrm{s.s.}}} \\
\quad(\mathrm{ppm})\end{array}$ & $\begin{array}{c}{\left[\mathrm{SO}_{4}{ }^{2-}\right]_{\text {s.s. +run-off }}} \\
(\mathrm{ppm})\end{array}$ & $\begin{array}{c}\text { total porcentaje conversión } \\
(\%) \\
\text { (total percentage } \\
\text { conversion (\%)) }\end{array}$ \\
\hline $\begin{array}{c}\mathrm{SO}_{2} \\
\mathrm{SO}_{2}+\mathrm{O}_{3} \\
\mathrm{SO}_{2}+\mathrm{H}_{2} \mathrm{O} \\
\mathrm{SO}_{2}+\mathrm{O}_{3}+\mathrm{H}_{2} \mathrm{O}\end{array}$ & $\begin{array}{l}11,9 \\
3,4 \\
2,5 \\
9,4\end{array}$ & $\begin{array}{c}11,9 \\
3,4 \\
117,2 \\
442,7\end{array}$ & $\begin{array}{l}0,7 \\
0,07 \\
2,4 \\
25,0\end{array}$ \\
\hline
\end{tabular}

\section{TABLA VIII (TABLE VIII)}

Concentración de sulfatos en las sales solubles y en los líquidos de lavado superficial; porcentaje de conversión del $\mathrm{SO}_{2}$ a sulfatos para los morteros a/c $=0,6$ al cabo de 8 semanas de exposición

Sulphate concentration in soluble salts and run-off; percentage of $\mathrm{SO}_{2}$ conversion for mortar of $w / c=0.6$ after 8 weeks exposure

\begin{tabular}{|c|c|c|c|}
\hline $\begin{array}{l}\text { Condiciones de } \\
\text { exposición } \\
\text { (Exposure } \\
\text { conditións) }\end{array}$ & $\begin{array}{c}{\left[\mathrm{SO}_{4}{ }^{2-}\right]_{\mathrm{s.s.}}} \\
(\mathrm{ppm})\end{array}$ & $\begin{array}{c}{\left[\mathrm{SO}_{4}{ }^{2-}\right]_{\text {s.s. +run-off }}} \\
\text { (ppm) }\end{array}$ & $\begin{array}{c}\text { total porcentaje conversión } \\
(\%) \\
\text { (total percentage } \\
\text { conversion (\%)) }\end{array}$ \\
\hline $\begin{array}{c}\mathrm{SO}_{2} \\
\mathrm{SO}_{2}+\mathrm{O}_{3} \\
\mathrm{SO}_{2}+\mathrm{H}_{2} \mathrm{O} \\
\mathrm{SO}_{2}+\mathrm{O}_{3}+\mathrm{H}_{2} \mathrm{O}\end{array}$ & $\begin{array}{l}7,0 \\
4,1 \\
3,2 \\
8,4\end{array}$ & $\begin{array}{c}7,0 \\
4,1 \\
28,5 \\
244,6\end{array}$ & $\begin{array}{c}0,4 \\
0,08 \\
0,6 \\
13,8\end{array}$ \\
\hline
\end{tabular}


oxidante. Comparando la conversión de $\mathrm{SO}_{2}$ a sulfato para los morteros expuesto en $\mathrm{SO}_{2}$ y en $\mathrm{SO}_{2}+\mathrm{O}_{3}+\mathrm{H}_{2} \mathrm{O}$, en el segundo caso es del orden de 35 veces superior al primero. Comparando las tablas VII y VIII con las tablas III-VI es evidente que la contribución de las sales solubles en agua al porcentaje total de conversión del $\mathrm{SO}_{2}$ es relativamente pequeño (aproximadamente $0,5 \%$ ).

La oxidación del $\mathrm{SO}_{2}$ se puede producir de forma (i) homogénea (oxidación en fase gas) o (ii) heterogénea (oxidación del $\mathrm{SO}_{2}$ (1)). Generalmente, para los morteros expuestos en ambientes de elevada humedad relativa (84\%) (en ausencia de agua líquida), la oxidación del $\mathrm{SO}_{2}(\mathrm{~g})$ debería ser pequeña (oxidación homogénea); en presencia de agua, la oxidación del $\mathrm{SO}_{2}$ aumenta debido a que se produce una oxidación heterogénea en la fase acuosa. En este estudio, la cámara se encuentra al $84 \%$ de humedad relativa, lo que produce la formación de una película de $2 \mathrm{~nm}$ de espesor, valor que puede aumentar dependiendo de la porosidad de las muestras (4).

En el caso de oxidaciones homogéneas, se ha establecido la velocidad de conversión del $\mathrm{SO}_{2}$ como $0,7 \mathrm{~h}^{-1}$, mientras que en presencia adicional de catalizadores este valor aumenta hasta valores próximos a $10 \mathrm{~h}^{-1}(2)$. En el caso de las oxidaciones heterogéneas, la etapa controlante es la oxidación del $\mathrm{SO}_{2}$ disuelto, ya que la absorción y disolución son etapas relativamente rápidas. Según Amoroso y Fassina (2) una gota de $5 \mu \mathrm{m}$ de diámetro, requiere 20 minutos para absorber $1 \mathrm{ppm}$ de $\mathrm{SO}_{2}$. Al aumentar la concentración del $\mathrm{SO}_{2}$ y el diámetro de la gota, también aumenta la velocidad de absorción. La oxidación heterogénea depende además de la presencia de catalizadores tales como óxidos de metales de transición ( $\mathrm{V}, \mathrm{Fe}, \mathrm{Mn}$, etc.) o de oxidantes $\left(\mathrm{O}_{3}, \mathrm{NO}_{2}\right.$, etc.). Penkett y colaboradores (13) estudiaron la oxidación de $\mathrm{SO}_{2}$ en gotas de la atmósfera, encontrando, que por ejemplo, al $\mathrm{pH}=6$ y en presencia de $\mathrm{O}_{2}$ se formaban $0,323 \mu \mathrm{m} \mathrm{SO}{ }_{4}^{2-} / \mathrm{min}$.; sin embargo, en presencia de $\mathrm{O}_{3}$, la concentración de $\mathrm{SO}_{4}^{2-}$ formados aumentaba hasta $62,4 \mu \mathrm{m} \mathrm{SO}_{4}^{2-} / \mathrm{min}$.

El porcentaje total de conversión de $\mathrm{SO}_{2}$ a sulfatos para los morteros expuestos en medio $\mathrm{SO}_{2}+\mathrm{O}_{3}$ es inferior al de los morteros expuestos en $\mathrm{SO}_{2}$ sólo, siendo ambos valores muy bajos, en concordancia con la relativamente pequeña reacción en la superficie "seca" (en realidad en equilibrio con el vapor de agua de la cámara al $84 \%$ de humedad relativa). Serán necesarios otros estudios que permitan explicar dicho comportamiento de los morteros.

Los resultados obtenidos indican claramente la importancia del agua en la reacción del $\mathrm{SO}_{2}$ con el mortero. Las figuras 3 y 4 muestran la variación con el tiempo del porcentaje de conversión de $\mathrm{SO}_{2}$ para los presence of ozone as oxidant. Compared with exposure to $\mathrm{SO}_{2}$ at $84 \%$ relative humidity, $\mathrm{SO}_{2}$ conversion to sulphate increased by about 35 times for exposure to $\mathrm{SO}_{2}$ plus water and oxidant. Comparing tables VII and VIII with tables III-VI is also generally evident that the contributions of retained salts to the total percentage conversion of $\mathrm{SO}_{2}$ is relatively small (about 0.5\%).

\section{Oxidation of $\mathrm{SO}_{2}$ may proceed by (i) homogeneous} (oxidation in the gas phase) and (ii) heterogeneous ( $\mathrm{SO}_{2}$ (l) oxidation) processes. Generally, for mortars exposed to $84 \%$ RH conditions (without water addition), relatively little gas phase oxidation of $\mathrm{SO}_{2}$ is expected (homogeneous oxidation); in the additional presence of water, the extent of oxidation increases, but this is through heterogeneous oxidation in the aqueous phase. In this study with a relative humidity in the chamber of $84 \%$, a relatively thin moisture film $(2 \mathrm{~nm})$ is present over the mortar surface, although increased values are expected within accessible pores (4).

An $\mathrm{SO}_{2}$ conversion rate of less than $0.7 h^{-1}$ has been determined for homogeneous oxidation (2) which, in the presence of catalysts, increases to about $10 h^{-1}$ (2). For heterogeneous oxidation, the controlling step is oxidation of dissolved $\mathrm{SO}_{2}$, since $\mathrm{SO}_{2}$ absorption and dissolution proceed relatively rapidly. According to Amoroso and Fassina (2), a 5 um radius raindrop requires about 20 minutes to absorb 1 ppm SO${ }_{2}$. The rate increases with $\mathrm{SO}_{2}$ concentration as well as the diameter of the raindrop. Heterogeneous oxidation also depends on the presence of catalysts such as transition metals oxides of $V, F e$ and $M n$, as well as the presence of oxidants $\mathrm{O}_{3}, \mathrm{NO}_{2}$, etc. Penkett et al. (13) studied the oxidation of $\mathrm{SO}_{2}$ in atmospheric droplets, for example showing that at $p H=6$, in the presence of $O_{2}, 0.323 \mu \mathrm{m}$ $\mathrm{SO}_{4}^{2} / \mathrm{min}$ were formed; on the other hand, $62.4 \mu \mathrm{m}$ $\mathrm{SO}_{4}^{2-} / \mathrm{min}$ were produced in the presence of $\mathrm{O}_{3}$.

Interestingly, the percentage conversion of $\mathrm{SO}_{2}$ to sulphate for exposure to $\mathrm{SO}_{2}+\mathrm{O}_{3}$ is less than that in the presence of $\mathrm{SO}_{2}$ alone, with both values being very low and consistent with relatively little reaction on a 'dry' surface (in reality at equilibrium with water vapour at a relative humidity of $84 \%)$. Further studies will be necessaries to understand the behaviour of the mortars.

From the results, it is evident that water plays an important role in the reaction between $\mathrm{SO}_{2}$ and the mortar. The variations of the percentage conversion of $\mathrm{SO}_{2}$ for mortars exposed to $\mathrm{SO}_{2}+\mathrm{H}_{2} \mathrm{O}$ and $\mathrm{SO}_{2}+\mathrm{O}_{3}+\mathrm{H}_{2} \mathrm{O}$ 
morteros expuestos en $\mathrm{SO}_{2}+\mathrm{H}_{2} \mathrm{O}$ y $\mathrm{SO}_{2}+\mathrm{O}_{3}+\mathrm{H}_{2} \mathrm{O}$. Dicho porcentaje de conversión se calcula sólo en base al líquido de lavado superficial. La figura 3 muestra el porcentaje de conversión del $\mathrm{SO}_{2}$ a sulfatos para los morteros expuestos en $\mathrm{SO}_{2}+\mathrm{H}_{2} \mathrm{O}$. En presencia de agua, la disolución del $\mathrm{SO}_{2}(\mathrm{~g})$ es una etapa rápida, siendo la oxidación la etapa controlante del proceso. Para los morteros relación $\mathrm{a} / \mathrm{c}=0,4$, la velocidad de conversión inicial del $\mathrm{SO}_{2}$ es rápida, lo que se atribuye a la rápida disolución del $\mathrm{SO}_{2}$ en la película de agua que existe sobre la superficie del mortero, su oxidación y la formación de una disolución ácida $\left(\mathrm{H}^{+}\right)$. La reacción química de estos protones con el $\mathrm{CaCO}_{3}$ del cemento produce iones $\mathrm{Ca}^{2+}$ los cuales, en presencia de iones $\mathrm{SO}_{4}{ }^{2-}$, generan sulfato cálcico que, en última instancia, darán yeso, el cual quedará retenido sobre la superficie de la muestra. Entre las semanas 2 y 7 de exposición, la reacción se ve decelerada, debido probablemente a que las sales formadas impiden el acceso de la disolución ácida a los centros activos. Sin embargo, con el tiempo se produce la llegada de más disolución ácida que producirá un aumento del $\mathrm{pH}$ del medio, favoreciendo de nuevo la reacción, de manera que a las 8 semanas de exposición la conversión de $\mathrm{SO}_{2}$ a sulfatos vuelve a aumentar. Resultados similares fueron encontrados por Spiker y colaboradores (14) para calizas y mármoles y por Gilardi (15) para ladrillos.

La figura 4 presenta el porcentaje de conversión de $\mathrm{SO}_{2}$ para los morteros expuestos en $\mathrm{SO}_{2}+\mathrm{O}_{3}+\mathrm{H}_{2} \mathrm{O}$. En estas condiciones, la disolución de $\mathrm{SO}_{2}(\mathrm{~g})$ procede como anteriormente, sin embargo, debido a la presencia de ozono en el medio, la oxidación es una etapa rápida, llegando al cabo de las 8 semanas a valores de conversión próximos al $25 \%$.

Con respecto a los morteros con relación $\mathrm{a} / \mathrm{c}=0,6$ (Figuras 3 y 4), con menor tamaño de poros, el conditions with time are shown in figures 3 and 4. In both figures the percentage conversion of $\mathrm{SO}_{2}$ is derived from run-off analyses. From figure 3, showing percentage conversion of $\mathrm{SO}_{2}$ for mortars exposed to $\mathrm{SO}_{2}+\mathrm{H}_{2} \mathrm{O}, \mathrm{SO}_{2}(\mathrm{~g})$ dissolution is a relatively fast step, whereas oxidation is the rate determining step. For mortars of $w / c=0.4$, the initial rate of $\mathrm{SO}_{2}$ conversion is relatively high, which can be attributed to $\mathrm{SO}_{2}$ dissolution in the moisture film present on the mortar and oxidation, producing an acid solution. Chemical reaction of protons with $\mathrm{CaCO}_{3}$ from cement mortar produces $\mathrm{Ca}^{2+}$ ions, which may run-off the surface or in the presence of $\mathrm{SO}_{4}^{2-}$ ions, generate calcium sulphate and ultimately gypsum which is retained in the near surface regions or on the surface. However, for the mortar of $w / c=0.4$ limited further reaction proceeds between 2 and 7 weeks exposure; after 8 weeks the percentage conversion of $\mathrm{SO}_{2}$ to sulphate is close to the early relatively high value. This possibly relates to calcium sulphate formation on, or near, the mortar surface with limits access of acid solution to react sites. However, with time, the $\mathrm{pH}$ of the solution increases again, and the access to unreacted material is possible and conversion of $\mathrm{SO}_{2}$ to sulphate proceeds. Similar behaviour was found by Spiker et al (14) on limestones and marbles and Gilardi (15) on bricks.

Figure 4 shows the percentage conversion of $\mathrm{SO}_{2}$ for mortars exposed to $\mathrm{SO}_{2}+\mathrm{O}_{3}+\mathrm{H}_{2} \mathrm{O}$. For this condition, $\mathrm{SO}_{2}(g)$ dissolution proceeds as previously indicated and subsequent oxidation is faster than in the absence of oxidant; thus the percentage conversion of $\mathrm{SO}_{2}$ is relatively high up to $25 \%$.

For the mortar $w / c=0.6$ of reduced pore size (Figures 3 and 4), water retention is more limited than for mortar

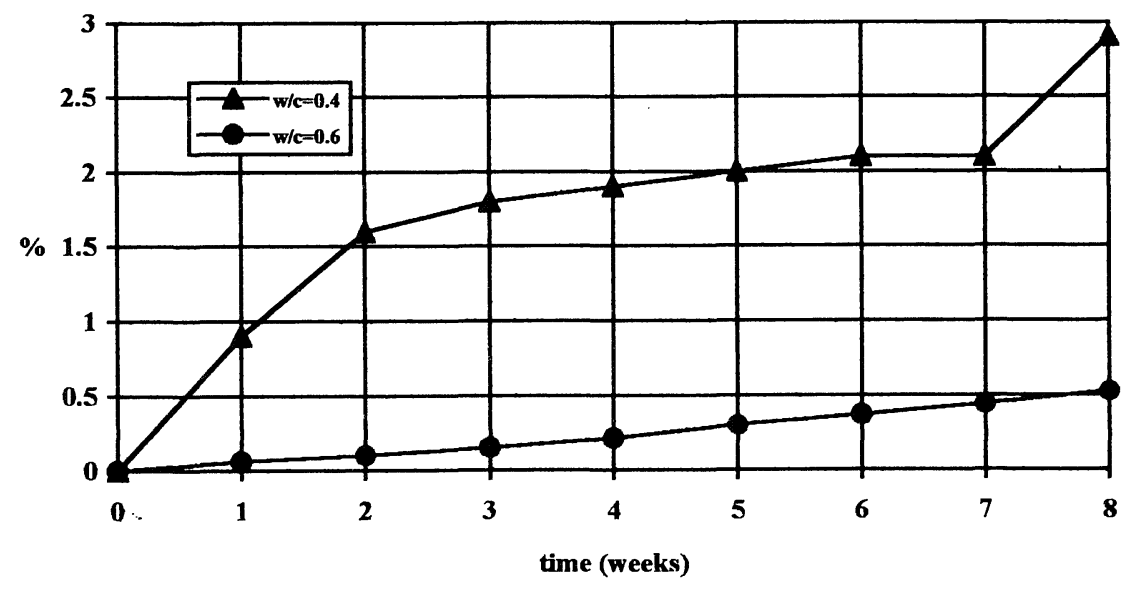

Fig. 3.- Porcentaje de conversión frente al tiempo de exposición en $\mathrm{SO}_{2}+\mathrm{H}_{2} \mathrm{O}$.

Fig. 3.- Percentage of conversion versus time in $\mathrm{SO}_{2}+\mathrm{H}_{2} \mathrm{O}$ exposure. 


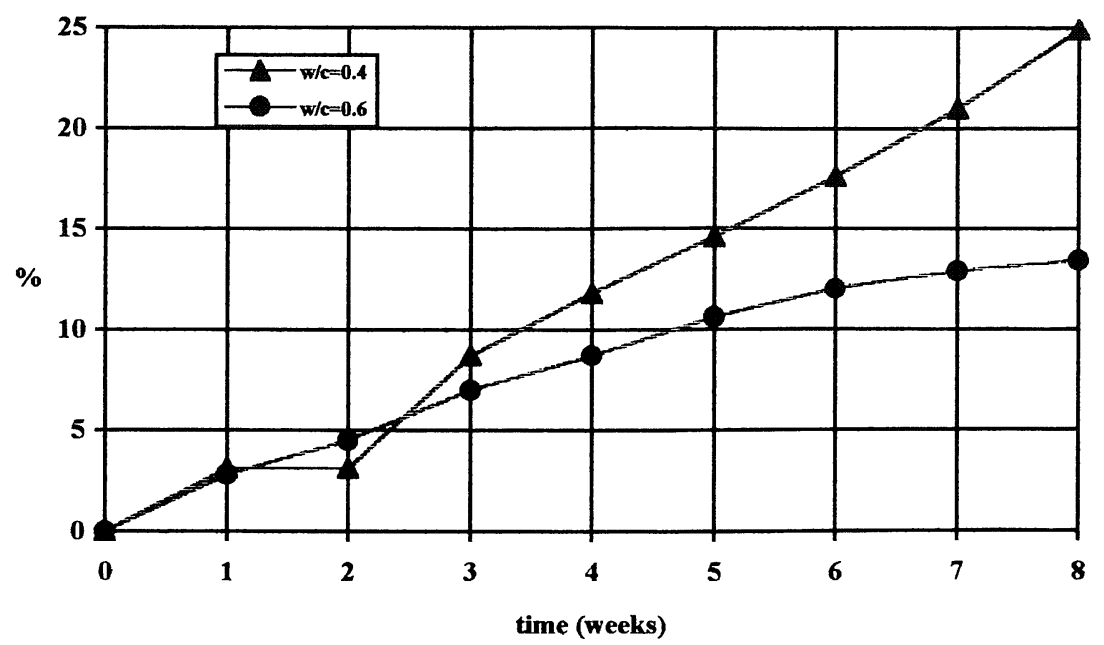

Fig. 4.- Porcentaje de conversión frente al tiempo de exposición en $\mathrm{SO}_{2}+\mathrm{O}_{3}+\mathrm{H}_{2} \mathrm{O}$.

Fig. 4.- Percentage of conversion versus time in $\mathrm{SO}_{2}+\mathrm{O}_{3}+\mathrm{H}_{2} \mathrm{O}$ exposure.

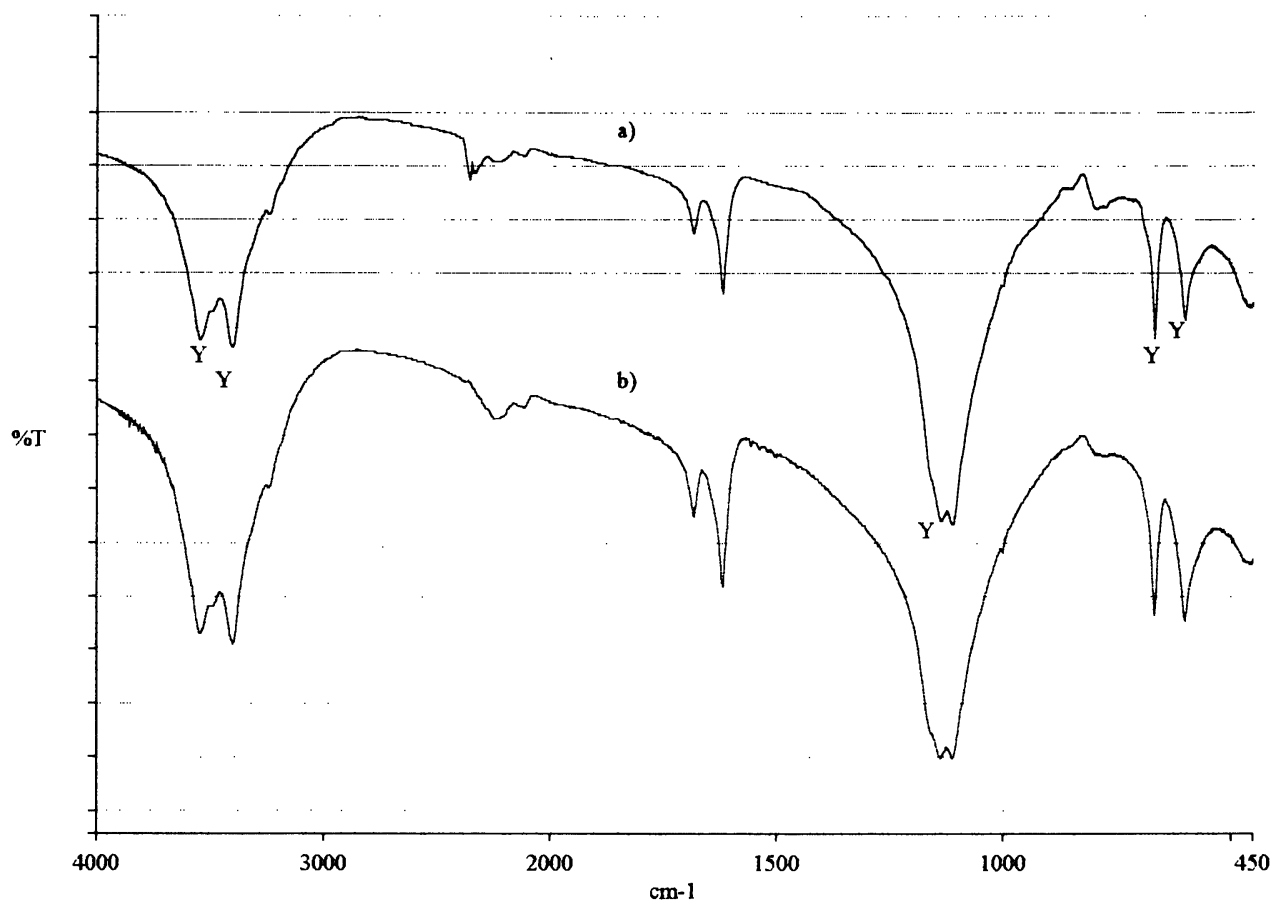

Fig. 5.- Espectro FTIR del mortero a/c $=0,4$ expuesto en $\mathrm{SO}_{2}+\mathrm{O}_{3}+\mathrm{H}_{2} \mathrm{O}$ : a) depósito marrón; b) depósito blanco.

Fig. 5.- FTIR spectra of $w / c=0.4$ ratio mortar under $\mathrm{SO}_{2}+\mathrm{O}_{3}+\mathrm{H}_{2} \mathrm{O}$ exposure: a) brown deposit; b) white deposit

porcentaje de conversión del $\mathrm{SO}_{2}$ a sulfatos es menor que para los morteros con relación $\mathrm{a} / \mathrm{c}=0,4$. En este caso y debido a su porosidad, la absorción de agua es un proceso más lento por lo que la reacción en la superficie del mortero es menor. Es interesante destacar que para estos morteros la velocidad de conversión de $\mathrm{SO}_{2}$ a sulfatos es prácticamente constante durante las 8 semanas de exposición.

Los depósitos blancos y marrones observados en la muestra se han atribuido a las diferentes sales formadas en la reacción entre el $\mathrm{CaCO}_{3}$ del mortero y el $\mathrm{SO}_{2}$; el espectro FTIR de dichos depósitos se ve en la figura 5 . of increased pore size, resulting in a lower percentage conversion of $\mathrm{SO}_{2}$ to sulphate through the reduced reaction time on the mortar surface. Interestingly, for mortars generally, the average rate of conversion of $\mathrm{SO}_{2}$ to sulphate is approximately constant over the 8 weeks exposure period.

The brown and white deposits, presents in the surface of the sample, have been attributed to different salts formed in the $\mathrm{SO}_{2}$-mortar reaction; FTIR of such deposits has been used to establish their composition (Figure 5). 
Las bandas de absorción a las frecuencias de 3.530, $3.404,1.621,1.163,1.137,1.110,670$ y $600 \mathrm{~cm}^{-1}$ provienen de las vibraciones del yeso, indicando que es la principal sal formada. Los datos de DRX confirman la presencia de dicha sal, por la aparición de una línea a $\mathrm{d}=7,74 \AA$, para los morteros expuestos 8 semanas en $\mathrm{SO}_{2}+\mathrm{O}_{3}+\mathrm{H}_{2} \mathrm{O}$.

La ausencia de la línea de difracción del yeso para los morteros con relación $\mathrm{a} / \mathrm{c}=0,4$ expuestos en medios con adición de agua, indican que las posibles sales formadas se arrastraron por el agua, bien en un proceso de lavado o por un arrastre mecánico.

\section{Deposición húmeda}

Después de 4 semanas de exposición en la cámara con rociado de la disolución, las muestras se secaron a $40^{\circ} \mathrm{C}$ y se determinaron las variaciones de peso. Los morteros con relación $\mathrm{a} / \mathrm{c}=0,6$ experimentaron un pequeño incremento de peso del $0,2 \%$. Sin embargo, los morteros con relación $\mathrm{a} / \mathrm{c}=0,4$ experimentaron una pequeña pérdida de peso. Estas pequeñas modificaciones de peso, indican que las sales formadas no han quedado retenidas en el mortero, sino que han sido arrastradas con la disolución rociada.

La morfología de las muestras se observó por SEM, viéndose que las muestras habían experimentado un gran deterioro, especialmente en los áridos (Figura 6). Aparecieron algunos cristales sobre la superficie de la muestra, cuyo análisis por EDAX revelaba la presencia de $\mathrm{S}$ y $\mathrm{Ca}$.

La composición mineralógica de la superficie de los morteros se determinó por FTIR (Figura 7). Para el mortero con relación $\mathrm{a} / \mathrm{c}=0,6$ se observaron bandas de absorción a las frecuencias de 3.530, 3.404, 1.621, 1.163, $1.137,1.110,670$ y $600 \mathrm{~cm}^{-1}$, confirmando la presencia de yeso anteriormente observada por SEM. En dicho espectro se observan además otras tres bandas a las frecuencias de $1.260 ; 800$ y $690 \mathrm{~cm}^{-1}$ de difícil asignación.

Con respecto al espectro FTIR de 1 mortero con relación $\mathrm{a} / \mathrm{c}=0,4$ (Figura 7), también presenta las absorciones a $1.260,800$ y $690 \mathrm{~cm}^{-1}$; por otro lado, las bandas de yeso no son tan claras como las del mortero con relación $\mathrm{a} / \mathrm{c}=0,6$. El estudio de los difractogramas de RX de ambos morteros no permitieron identificar ninguna fase nueva, por lo que se necesitarán estudios posteriores para la identificación de las bandas de que aparecen en los espectros FTIR.

La morfología de los morteros $\mathrm{a} / \mathrm{c}=0,4$ se analizó por SEM, observándose el crecimiento de pequeños cristales cuya composición por EDAX revelaba Ca y S (Figura 8), lo que confirma las pequeñas bandas de absorción en el espectro FTIR.
Absorption frequencies at 3.530, 3.404, 1.621, 1.163, $1.137,1.110,670$ and $600 \mathrm{~cm}^{-1}$ arise from gypsum, indicating the main composition of the salts formed. The data are confirmed by XRD, of the samples after exposure to $\mathrm{SO}_{2}+\mathrm{O}_{3}+\mathrm{H}_{2} \mathrm{O}$ for 8 weeks, when a sharp band is evident at $d=7.74 \AA$ arising from the presence of gypsum.

The absence of gypsum bands from XRD of mortars of $w /$ $c=0.4$ exposed to $\mathrm{SO}_{2}+\mathrm{H}_{2} \mathrm{O}$ indicate that water addition carry away the salts formed, either water washing or mechanical removing.

\section{Wet deposition}

After exposure for 4 weeks in the salt spray cabinet, the samples were dried $\left(40^{\circ} \mathrm{C}\right)$ and weight changes determined. An increases of weight of $0.2 \%$ was observed for mortars of $w / c=0.6$. However, small weight losses, about $-0.1 \%$ were evident for mortars of $w / c=0.4$. Such small weight changes suggest that more of the formed salts are soluble in water and have been washed in wet cycle.

Morphological observations of the mortars of $w / c=0.6$ by SEM revealed significant sample disruption, particularly in aggregates (Figure 6). Some crystals had also developed over the surface, with EDX elemental analysis revealing the presence of $S$ and $C a$.

In order to determine mineralogical composition of the exposed surface of the mortar of $w / c=0.6$, as well as the possible salts formed, samples were analysed by FTIR (Figure 7). Absorption frequencies at 3.530, 3.404, $1.621,1.163,1.137,1.110,670$ and $600 \mathrm{~cm}^{-1}$ indicated gypsum presence in the sample surface, in agreement with the crystals showed in SEM. A further three bands, at frequencies of $1.260,800$ and $690 \mathrm{~cm}^{-1}$ are also present.

FTIR spectra for the exposed mortar of $w / c=0.4$ ratio also revealed absorptions at 1.260, 800 and $690 \mathrm{~cm}^{-1}$ (Figure 7). On the other the hand gypsum bands are not as clear as for mortar of $w / c=0.6 . X R D$ of the mortars exposed in wet conditions did not reveal any new phase; further studies will be necessaries to identify those FTIR bands.

The morphology of the mortars of $w / c=0.4$ was analyse by SEM showing small crystals growing in the sample (Figure 8); elemental composition of this crystals determined from $E D A X$ revealed $C a$ and $S$, in agreement with FTIR results. 


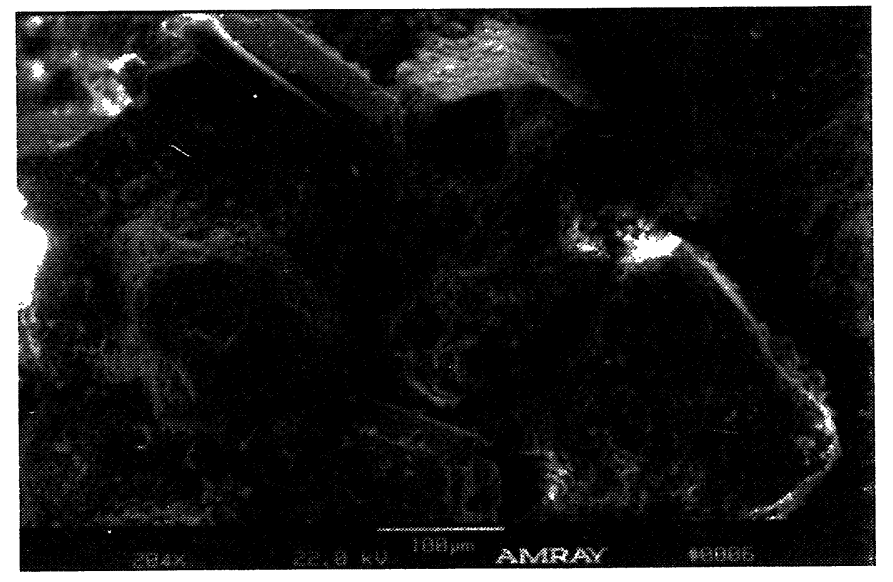

Fig. 6.- Morfología de los morteros $\mathrm{a} / \mathrm{c}=0,6$ por SEM.

Fig. 6.- Morphology of the mortars of $w / c=0.6$ by SEM.

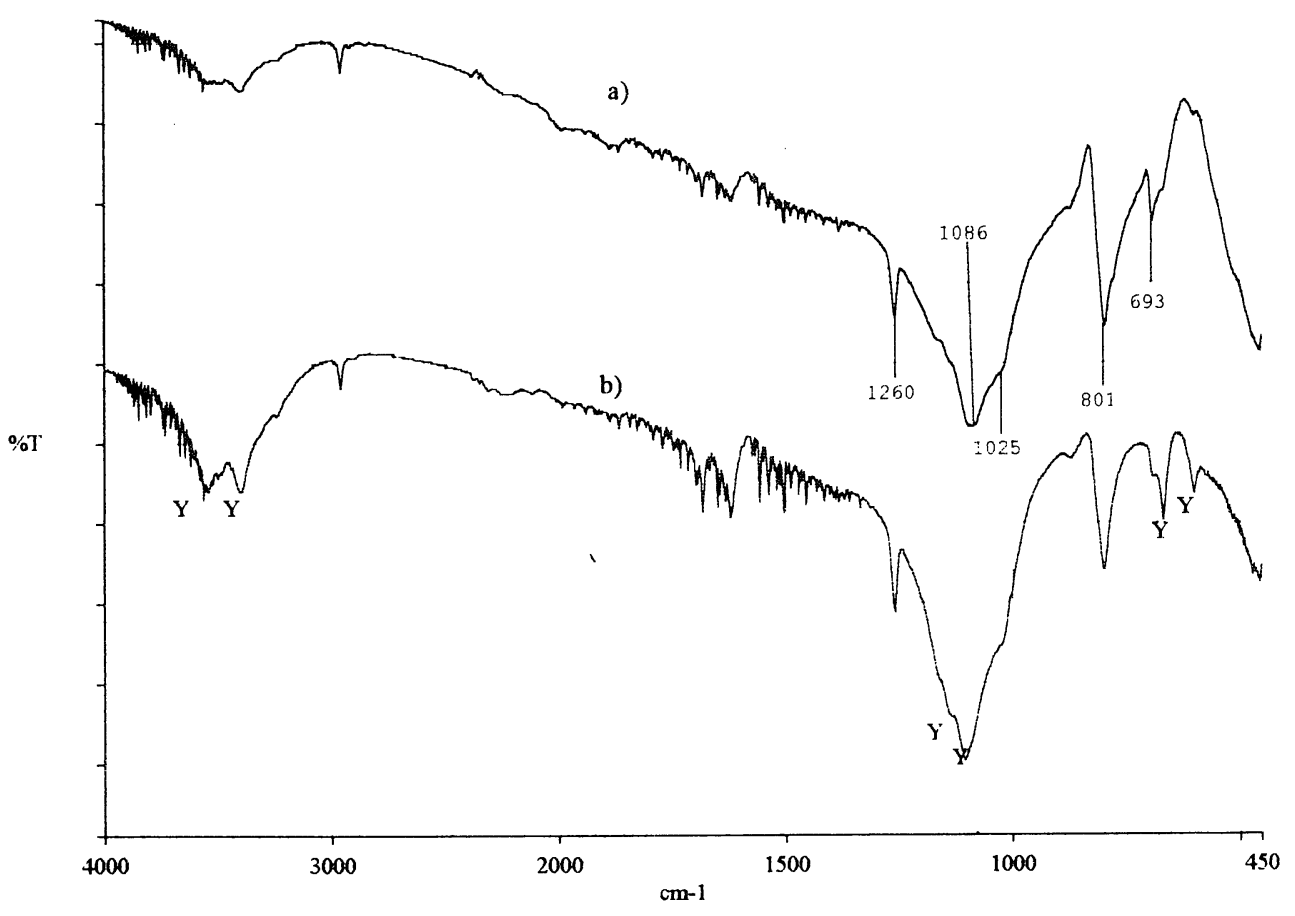

Fig. 7.- Espectro FTIR de los morteros expuestos en "lluvia ácida" 90 dias: a) mortero $\mathrm{a} / \mathrm{c}=0,4 ; \mathrm{b}$ ) mortero $\mathrm{a} / \mathrm{c}=0,6$.

Fig. 7.- FTIR spectra of the mortar exposed in 2acid rain" 90 days for: a) $w / c=0.4$ ratio mortar; b) $w / c=0.6$ ratio mortar.

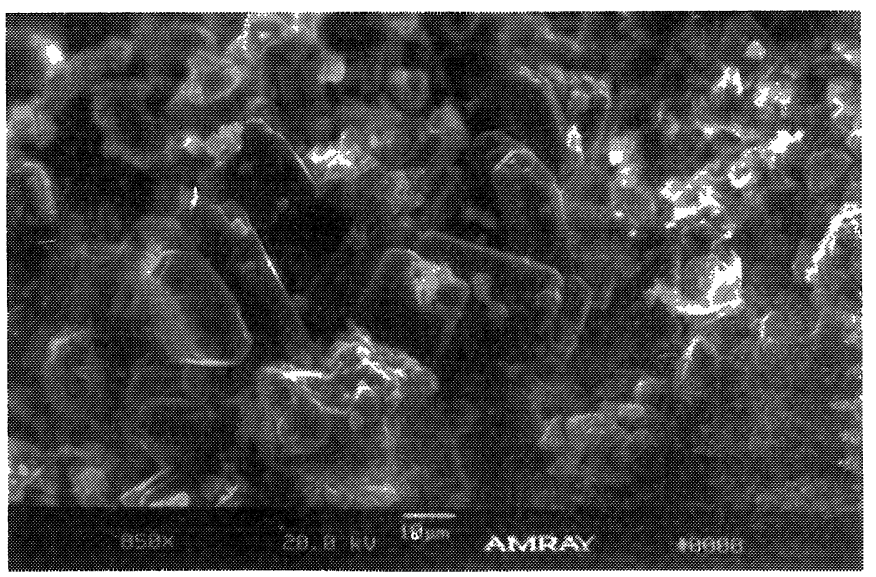

MATERIALES DE CONSTRUCCIÓN, Vol $48, n^{\circ} 250$, abril/mayo/junio 1998
Fiig. 8- Morfologia de los morteros a/c $\cdots 0,4$ por Si:M.

Fig. 8. - Morphology of the mortars of w/e $=0.4$ by SH:M. 


\section{CONCLUSIONES}

1.- Los estudios en las cámaras del laboratorio de simulación de "deposiciones" de contaminantes en condiciones secas y húmedas para morteros de cemento carbonatados superficialmente, revelan que el principal producto de la reacción es el yeso; las propiedades físicas del mortero juegan un papel importante en la reacción con los contaminantes.

2.- Para la deposición seca de $\mathrm{SO}_{2}$, la reacción química entre los componentes del mortero y los gases agresivos aumenta en el siguiente orden:

\section{CONCLUSIONS}

1.- Laboratory-based chambers studies, involving dry and wet deposition of pollutants, for cement mortars with the external surface carbonated, reveal gypsum formation as the main reaction product; the physical properties of the mortar also play important roles in the reaction with pollutants.

2.- For dry deposition of $\mathrm{SO}_{2}$ pollutant gas, chemical reaction increases in the order

$$
\mathrm{SO}_{2}<\mathrm{SO}_{2}+\mathrm{O}_{3}<\mathrm{SO}_{2}+\mathrm{H}_{2} \mathrm{O}<\mathrm{SO}_{2}+\mathrm{O}_{3}+\mathrm{H}_{2} \mathrm{O}
$$

revelando la importancia del agua y el oxidante. La reacción química del $\mathrm{SO}_{2}$ con los componentes del mortero en presencia de oxidante y agua es 35 veces mayor que en presencia de $\mathrm{SO}_{2}$ sólo.

3.- Para los morteros expuestos en medios con adición de agua, el porcentaje de conversión del $\mathrm{SO}_{2}$ a sulfato aumenta al disminuir la reacción a/c, lo que produce una mayor cantidad de agua retenida y, por tanto, un menor tiempo para que se produzca la reacción.

4.- La exposición de los morteros en disolución de 'lluvia ácida', revela que se produce la formación de yeso, que fue mayor para los morteros de mayor relación $\mathrm{a} / \mathrm{c}$.

\section{AGRADECIMIENTOS}

Los autores desean agradecer a la Dirección General de Investigación y Tecnología de España la concesión de una beca para la realización de este trabajo. revealing the importance of water and oxidant in the overall decay. The extent of chemical reaction in the additional presence of water plus oxidant is about 35 times greater that for $\mathrm{SO}_{2}$ alone.

3.- For wetted mortars, the percentage conversion of $\mathrm{SO}_{2}$ to sulphate increased as the $w / c$ ratio decreased, reflect increased water retention, and hence time for reaction.

4.- Exposure to artificial 'acid rain' solution revealed gypsum formation which was more extensive for the mortars of increased $w / c$ ratio.

\section{ACKNOWLEDGEMENTS}

The authors wish to thank to Direccion General de Investigación y Tecnologia from Spain that support the present work with a grant.

\section{BIBLIOGRAFÍA}

(1) The effects of acid rain deposition on building and building materials in the United Kingdom, Berg Report (Building Effects Review Group), HMSO, London (1989).

(2) G. AMOROSO AND V. FASSINA. Stone decay and conservation, 1st Ed., (Elsevier Amsterdam) (1983).

(3) A.J. LEWRY; D.J. BIGLAND AND R.N. Butlin. "A chamber study of the effects of sulphur dioxide on calcareous stone". $7^{\text {th }}$ International Congress on Deterioration and Conservation of Stone, Lisbon, 641-650 (1992).

(4) S.J. HANEEF; J.B. JOHNSON; C. DICKINSON; G.E. THOMPSON AND G.C. WOOD. "Effect of dry deposition of NO and $\mathrm{SO}_{2}$ gaseous pollutants on the degradation of calcareous building stones". Atmospheric Environment, 26A, 2963-2974 (1992).

(5) F. GIRARDET; V. FURLAN; E.P. AUSSET; M. DEL MONTE D. JEANNET AND R.A. LEFEVRE. "Etude expsrimentale de la prise en souffre d'un calcaire et d'un gres calcareux dans la chambre de simulation atmospherique de Laussane", g $^{\text {h International }}$ Congress on Deterioration and Conservation of Stone, Berlin, 349-358 (1996). 
(6) F. GIRARDET AND V. FURLAN. "Reactivite des puierres au $\mathrm{SO}_{2}$ atmospherique, etude en chambre de simulation et correlation avec les mesures en site". $8^{\text {th }}$ International Congress on Deterioration and Conservation of Stone, Berlin, 341 -347 (1996).

(7) F. DE SANTIS; D. PASELLA AND I. ALLEGRINI. "A diffusion technique for the evaluation of surface reactivity: application to the study of $\mathrm{SO}_{2}$ deposition on marble". III International Symposium on the Conservation of Monuments in the Mediterranean Basin, Venice, 213-216 (1994).

(8) E.C SPIKER; V.J. COMER; R.P HOSTER AND S.I. SHERWOOD. "Dry deposition of $\mathrm{SO}_{2}$ on limestone and marble: role of humidity". $7^{\text {th }}$ International Congress on Deterioration and Conservation of Stone, Lisbon, 397-406 (1992).

(9) J.F.HENRIKSEN. "Dry deposition on stone surfaces: preliminary norwegian results from a EEC-STEP project". III International Symposium on the Conservation of Monuments in the Mediterranean Basin, Venice, 189-193 (1994).

(10) H.L. KONG AND J.G. ORBISON. “Concrete Deterioration Due to Acid Precipitation”. ACI Materials Journal, 84, 110-116 (1987).

(11) H. OKOCHI. "Deterioration of concrete structure by acid deposition". Corrosion Engineering, 44, 813-827 (1995).

(12) G. ZAPPIA; C. SABBIONI; M.G. PAURI AND G. GOBBI. "Mortar damage due to airborne sulphur compounds in a simulation chamber". Materials and Structure 27, 469-473 (1994).

(13) S.A.PENKETT; B.A.R. JONES AND A.E.J. EGGLETON. “A study of $\mathrm{SO}_{2}$ oxidation in stored rainwater samples". Atmospheric Environment, 33, 139-147 (1979).

(14) E.C SPIKER; R.P. HOSKER; V.J. COMER; J.R. WHITE; R.W. WERRE JR.; F.L. HARMON; G.D. GANDY AND S.I. SHERWOOD. "An environmental chamber for studying the deposition flux of gaseous pollutants to material surfaces". Atmospheric Environment, 26A, 2885-2892 (1992).

(15) E.F. GILARDI. “Absorption of atmospheric sulfur-dioxide by clay, brick and other building materials". PhD dissertation, Rutergs 1966.

\section{publicación del IETCC/CSIC}

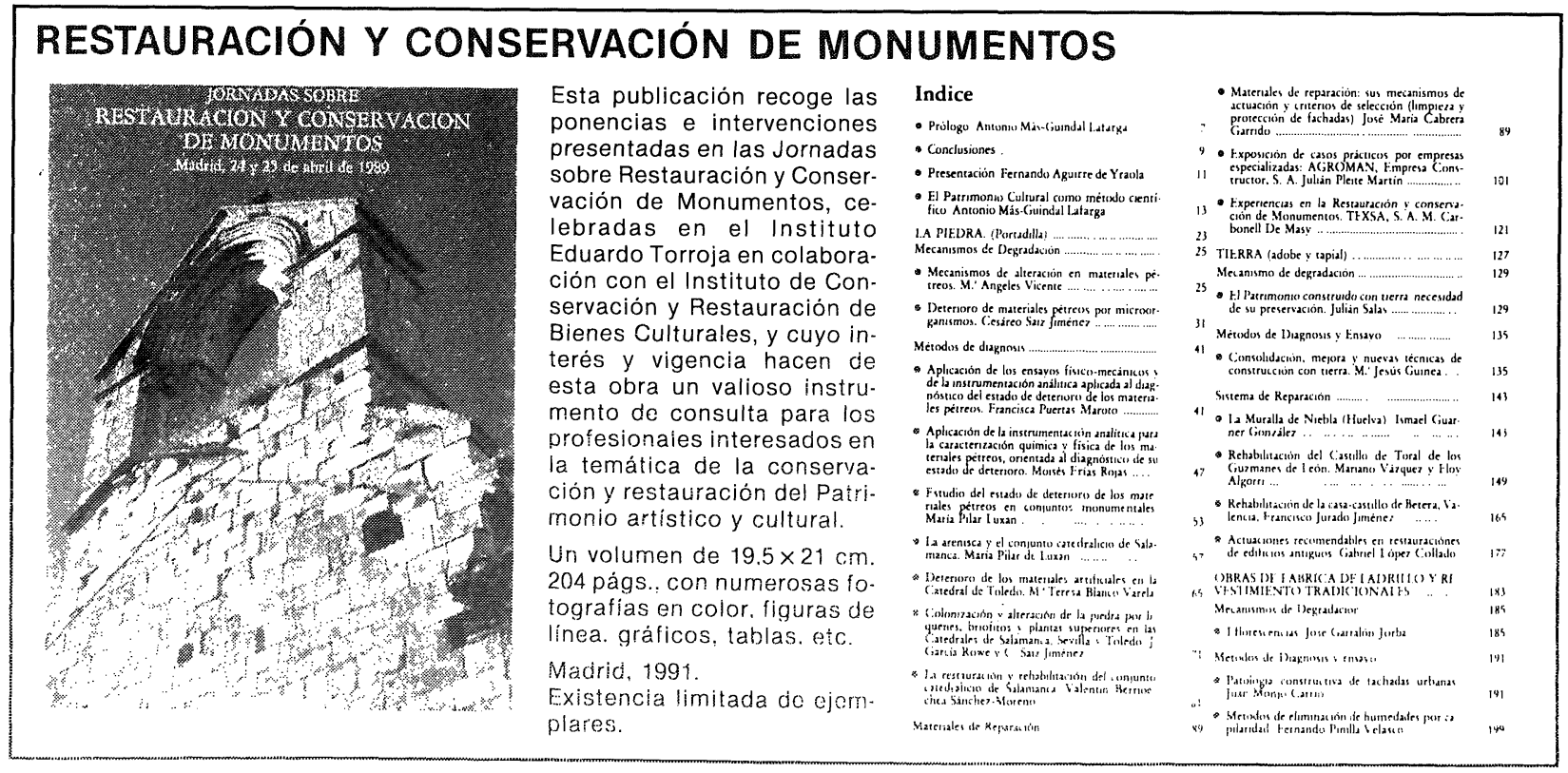

